\title{
The year in cardiovascular medicine 2020
}

Citation for published version (APA):

Crijns, H. J. G. M., Prinzen, F., Lambiase, P. D., Sanders, P., \& Brugada, J. (2021). The year in cardiovascular medicine 2020: arrhythmias. European Heart Journal, 42(5), 499-507.

https://doi.org/10.1093/eurheartj/ehaa1091

Document status and date:

Published: 01/02/2021

DOI:

10.1093/eurheartj/ehaa1091

Document Version:

Publisher's PDF, also known as Version of record

Document license:

Taverne

Please check the document version of this publication:

- A submitted manuscript is the version of the article upon submission and before peer-review. There can be important differences between the submitted version and the official published version of record.

People interested in the research are advised to contact the author for the final version of the publication, or visit the DOI to the publisher's website.

- The final author version and the galley proof are versions of the publication after peer review.

- The final published version features the final layout of the paper including the volume, issue and page numbers.

Link to publication

\footnotetext{
General rights rights.

- You may freely distribute the URL identifying the publication in the public portal. please follow below link for the End User Agreement:

www.umlib.nl/taverne-license

Take down policy

If you believe that this document breaches copyright please contact us at:

repository@maastrichtuniversity.nl

providing details and we will investigate your claim.
}

Copyright and moral rights for the publications made accessible in the public portal are retained by the authors and/or other copyright owners and it is a condition of accessing publications that users recognise and abide by the legal requirements associated with these

- Users may download and print one copy of any publication from the public portal for the purpose of private study or research.

- You may not further distribute the material or use it for any profit-making activity or commercial gain

If the publication is distributed under the terms of Article $25 \mathrm{fa}$ of the Dutch Copyright Act, indicated by the "Taverne" license above, 


\section{The year in cardiovascular medicine 2020: arrhythmias}

\section{Harry J.G.M. Crijns (1) ${ }^{1}$, Frits Prinzen $\mathbb{1}^{2}$, Pier D. Lambiase $\mathbb{( D )}^{3}$, Prashanthan Sanders ${ }^{4}$, and Josep Brugada (1) ${ }^{5}$}

${ }^{1}$ Department of Cardiology and Cardiovascular Research Centre Maastricht (CARIM), Maastricht University Medical Centre, Maastricht, The Netherlands; ${ }^{2}$ Department of Physiology and Cardiovascular Research Centre Maastricht (CARIM), University of Maastricht, Maastricht, The Netherlands; ${ }^{3}$ University College London \& Barts Heart Centre, London, UK; ${ }^{4}$ Centre for Heart Rhythm Disorders, University of Adelaide and Royal Adelaide Hospital, Adelaide, Australia; and ${ }^{5}$ Cardiovascular Institute, Hospital Clinic, Pediatric Arrhythmia Unit, Hospital Sant Joan de Déu, University of Barcelona, Barcelona, Spain

\section{Graphical Abstract}
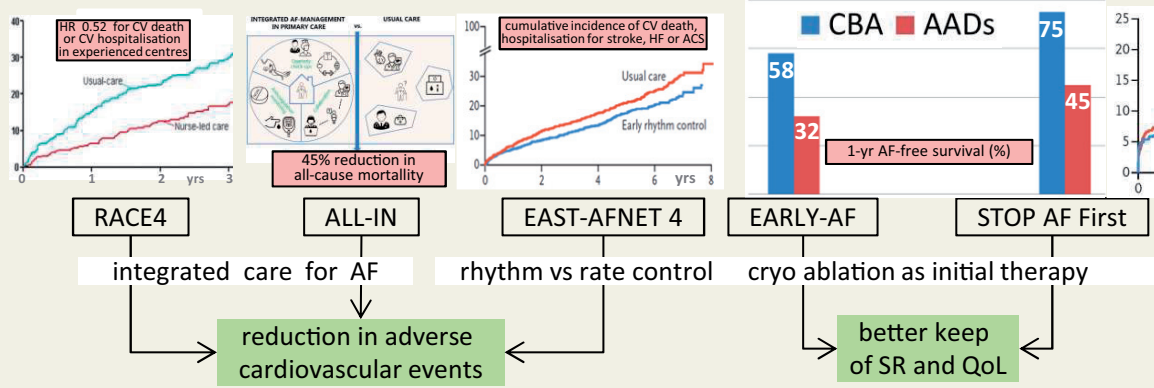

rhythm vs rate control
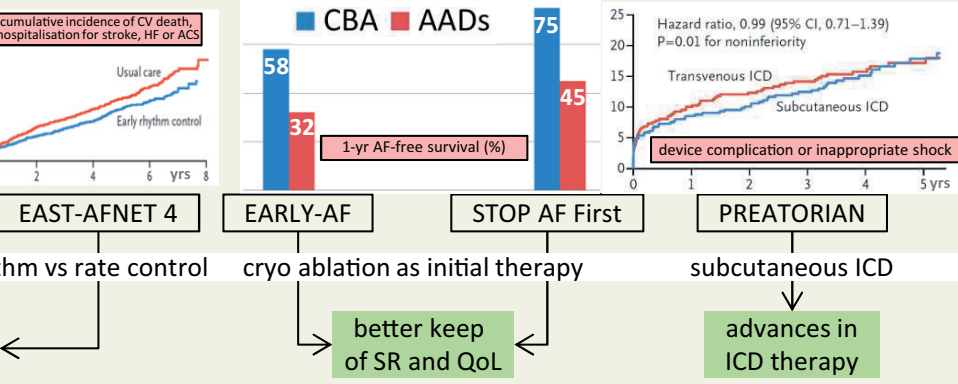

$\downarrow$

advances in

ICD therapy

randomised clinical trials

THE YEAR IN CARDIOVASCULAR MEDICINE - ARRHYTHMIAS 2020

mechanistic studies

risk assessement

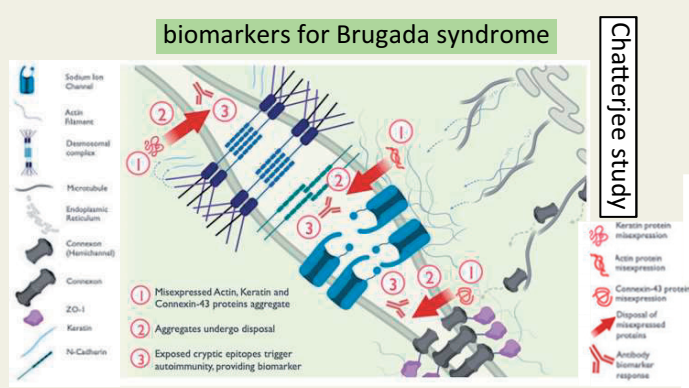

improvedLV-contractility

improved risk scoring in IHD
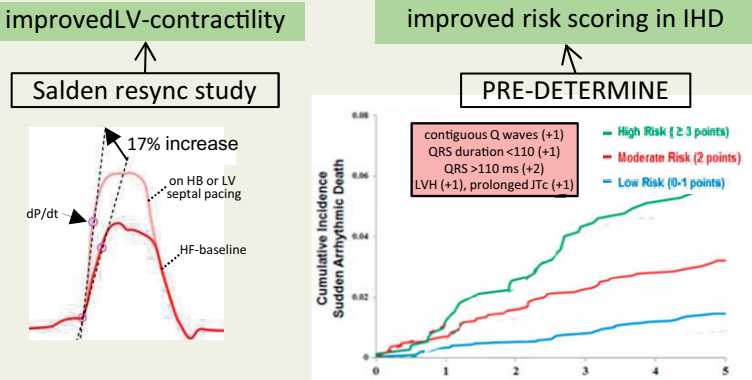

Summary of the progress in arrhythmias in 2020. RACE4 and ALL-IN indicated that integrated nurse-led care improves outcomes in AF patients. ${ }^{3,4}$ The same was reported for early rhythm control therapy ${ }^{15}$ and cryoablation as initial AF treatment. ${ }^{25,26}$ Subcutaneous ICD was non-inferior to classical transvenous ICD therapy in PRAETORIAN. ${ }^{54}$ One mechanistic study showed that autoantibodies against misexpressed actin, keratin, and connexin-43 proteins create a blood-borne biomarker profile enhancing diagnosis of Brugada syndrome. ${ }^{50}$ Another mechanistic study indicated that transseptal LV pacing yields similar improvement in contractility as His bundle pacing whilst being more easy to execute. ${ }^{44}$ In PRE-DETERMINE a simple-to-use ECG risk score improved risk prediction in patients with ischemic heart disease possibly enhancing appropriate ICD therapy in high risk patients. ${ }^{58}$

* Corresponding author. Tel: +31 433875093, Fax:+31433875104, Email: hjgm.crijns@mumc.nl

Published on behalf of the European Society of Cardiology. All rights reserved. (c) The Author(s) 2021. For permissions, please email: journals.permissions@oup.com. 


\section{Introduction}

The Year in Cardiovascular Medicine: Arrhythmias 2020 reviews the most relevant studies in the field of arrhythmias and pacing. The past year has shown a significant progress: landmark clinical trials in atrial fibrillation (AF) and implantable defibrillator (ICD) therapy, new guidelines, integrated care, life style and arrhythmias, His bundle pacing, risk prediction in sudden cardiac death, and advances in cardiogenetics.

\section{New guidelines}

The guidelines on supraventricular tachycardia (SVT) and AF brought many new insights and recommendations. ${ }^{1,2}$ The former dealt with SVT ablation as an early strategy and invasive risk assessment in ventricular preexcitation. Its focus also was on what-to-avoid in management of SVT. ${ }^{2}$ The new guidelines on AF promote the slogan ' $\mathrm{CC}$ to $A B C$ ', indicating that electrical Confirmation of $A F$ is mandatory together with in-depth Characterisation of AF (Figure 1). ${ }^{1}$ For management the AF guidelines advise to follow the Atrial fibrillation Better Care $(A B C)$ pathway, which represents care to (i) avoid stroke, (ii) better symptom control, and (iii) take care of co-morbidities and cardiovascular risk factors. Despite the lack of data to show clinical effectiveness, AF screening is advocated saying that once $A F$ is detected outcome worsens. It is also recommended to measure the quality of care over time and when needed improve care in an iterating cycle of improvement. The guidelines also highlight the importance of longitudinal rather than one-time cross-sectional assessment of stroke and bleeding risks since patients may outgrow their low risk status quite rapidly over time. Catheter ablation is advocated to ameliorate $\mathrm{AF}$ symptoms and to manage $\mathrm{AF}$-associated heart failure and may be applied after one antiarrhythmic drug failure including failure on beta-blockade.

\section{Randomized trials on integrated care in atrial fibrillation}

Interesting randomized trials on integrated $\mathrm{AF}$ management included the ALL-IN trial, a cluster randomized trial in elderly AF patients in primary care, which showed that integrated care delivered by practice nurses supervised by general practitioners reduced all-cause mortality by $45 \%$ compared to usual-care. ${ }^{3}$ This is impressive and highlights the power of 'simple' interventions if deployed systematically. The integrated care pathway included quarterly AF check-ups by the practice nurse, case management of antithrombotic treatment, and easy-access consultation of a cardiologist. This represents patient-centered shared responsibilities between primary care, anticoagulation clinics, cardiologists, and patients. Similarly, RACE 4 reported that nurse-led, information and communication technology (ICT)-supported, and physician-supervised integrated care reduces morbidity and mortality in experienced centres but not in lessexperienced centres and emphasized the importance of training in an integrated environment. ${ }^{4}$ Key elements of integrated care in these trials were the multidisciplinary team approach, education, and empowerment of patients and where possible application of decision support technology.

Recent $\mathrm{mH}$ ealth solutions include TeleCheck- $\mathrm{AF}^{5,6}$ and a mobile AF application incorporating the ABC pathway (Figure 1). ${ }^{7}$ The mAFA II trial reported a significant reduction in all-cause death and adverse cardiovascular events compared to routine management in high-risk AF. ${ }^{7}$ Notably, single elements of integrated care such as application of a clinical decision support system, ${ }^{8}$ an educational ${ }^{9}$ or a motivational ${ }^{10}$ intervention to improve anticoagulation or introduction of shared decision-making ${ }^{11}$ improve the level of care but not prognosis.

In integrated care, patient-driven life-style changes targeting obesity, alcohol, and blood pressure control is important before performing rhythm control with catheter ablation. In a large cohort of 402406 individuals from the UK Biobank, regular physical activity was related with a lower incidence of AF (especially in women) and ventricular arrhythmias but not of bradyarrhythmias. ${ }^{12}$ Also, a randomized trial provided proof-of-concept data to support alcohol cessation as secondary prophylaxis against AF in regular drinkers. ${ }^{13}$ Per nature of the trial, it focused on one element of life style whilst a more comprehensive multi-level modification of AF risk factors may be needed to abrogate risks of AF in daily life. ${ }^{14}$

\section{Randomized trials on rhythm control in atrial fibrillation}

The EAST-AFNET 4 trial compared a rhythm with a rate control strategy in patients with early AF lasting $<1$ year. It showed that rhythm control therapy, i.e. antiarrhythmic drugs and ablation, in early AF reduced cardiovascular outcomes without increasing time spent in-hospital, and without safety concerns. ${ }^{15}$ The results are at odds with older trials, which may relate to earlier intervention, safer use of antiarrhythmic drugs, and safe application of catheter ablation. In accordance with the AF Guidelines, ${ }^{1,16-18}$ rhythm control was applied on top of cardiovascular prevention. Like previous trials, ${ }^{19-21}$ EAST-AFNET4 was a strategy evaluation and not a simple comparison of two treatment modalities meant to either maintain sinus rhythm or keeping adequate rate control like the CABANA trial. ${ }^{22}$ EASTAFNET4 included recently detected AF, which seems crucial since most events occur in the first year after AF detection. ${ }^{23,24}$ Early intervention is supported by two recent trials showing that cryoballoon ablation as initial therapy is superior to drug treatment. ${ }^{25,26}$ Therefore, initial AF care should be supervised by cardiologists rather than non-cardiologists since 1-year mortality and morbidity are lower if newly diagnosed $A F$ is managed under cardiology care compared to non-cardiology care. ${ }^{27,28}$ 


\section{To ABC}

\section{Confirm AF}

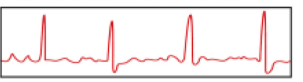

A 12-lead ECG or a rhythm strip showing AF pattern for $\geq 30 \mathrm{~s}$

\section{Characterise AF (the 4S-AF scheme)}

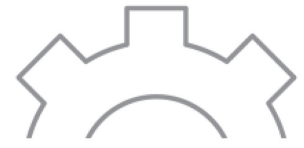

Stroke risk (St)

(e.g., $\mathrm{CHA}_{2} \mathrm{DS}_{2}$-VASc score)
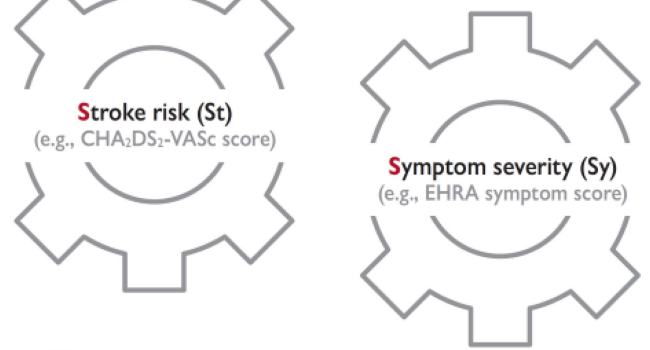

Treat AF: The ABC pathway

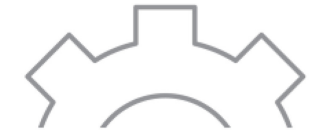

Severity of AF burden (Sb) (duration, spontaneous termination)

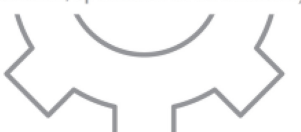

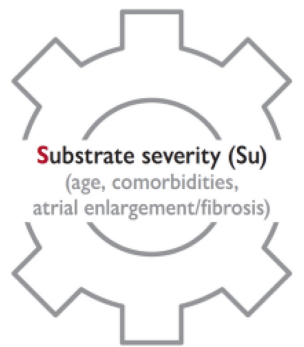
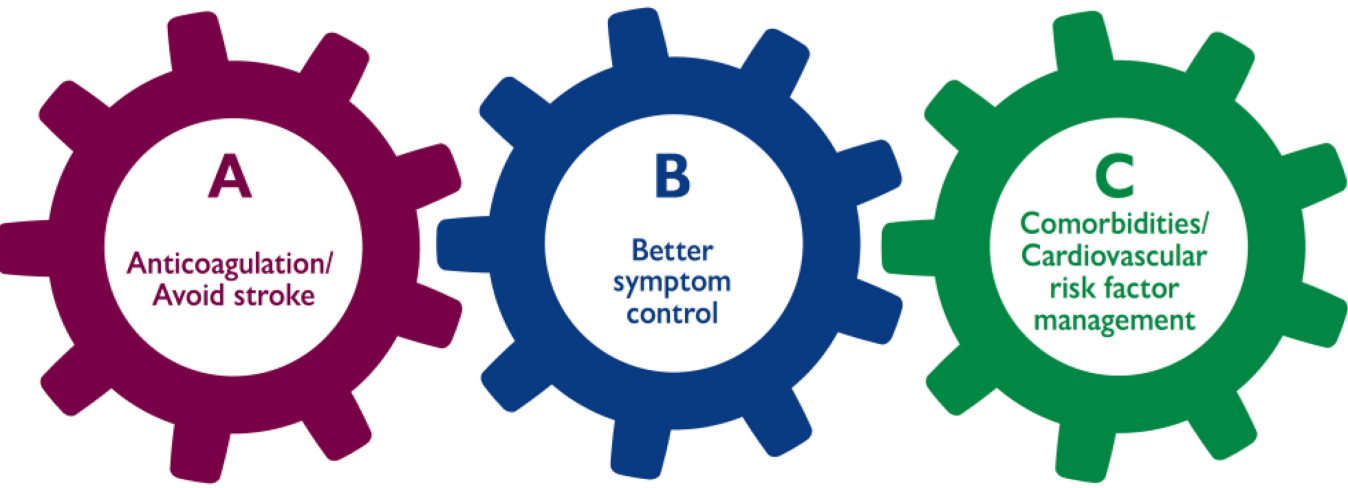

1. Identify low-risk patients $\mathrm{CHA}_{2} \mathrm{DS}_{2}$-VASc 0 (m), 1 (f)

2. Offer stroke prevention if $\mathrm{CHA}_{2} \mathrm{DS}_{2} \mathrm{VASc} \geq 1(\mathrm{~m}), 2$ (f)

Assess bleeding risk, address modifiable bleeding risk factors

3. Choose OAC (NOAC or VKA with well-managed TTR)

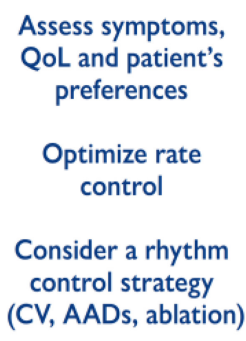

Assess symptoms, QoL and patient's preferences

Optimize rate control

Consider a rhythm control strategy (CV, AADs, ablation)

Comorbidities and cardiovascular risk factors

Lifestyle changes (obesity reduction, regular exercise, reduction of alcohol use, etc.)

Figure I The CC to Atrial fibrillation Better Care paradigm in the latest European Society of Cardiology (ESC) guidelines provides a comprehensive and holistic approach towards diagnosis and management of atrial fibrillation. CC stands for Confirmation (first C) and Characterisation (second C) of atrial fibrillation according to the structured 4S-AF scheme including assessment of stroke risk, symptom severity, severity of atrial fibrillation burden, and substrate severity. Reproduced with permission from Ref. ${ }^{1}$

Early rhythm control in recent-onset AF in the emergency room was tested in another randomized study comparing procainamide and rescue electrical cardioversion if needed with immediate electrical cardioversion. ${ }^{29}$ Both strategies were clinically highly effective, but the authors suggested that immediate cardioversion be preferred since less burdensome for patients and the hospital. 


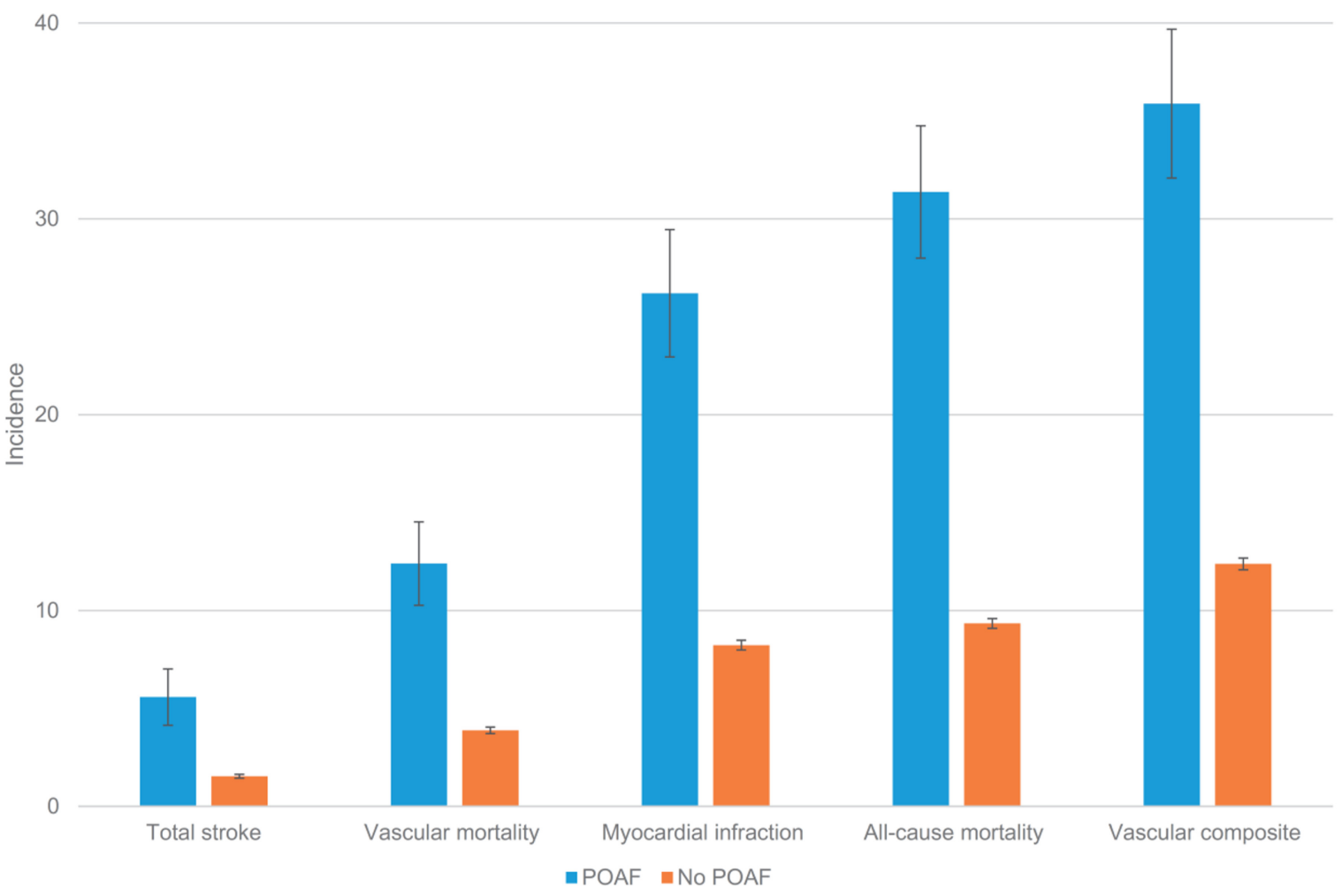

Figure 2 Adverse events per 100 patient-years follow-up in patients with cardiovascular disease after non-cardiac surgery indicate that postoperative atrial fibrillation is associated with a significantly elevated incidence of cardiovascular adverse events. Reprinted with permission from Ref. ${ }^{39}$

Catheter ablation may be particularly useful in heart failure with $A F,{ }^{21,30}$ to improve quality of life $e^{31,32}$ as well as to save costs. ${ }^{33}$ One interesting observational study suggested that catheter ablation compared to drug treatment is associated with a lower incidence of vascular dementia. ${ }^{34}$ To support or circumvent catheter ablation, recent reports advocated add-on renal denervation ${ }^{35}$ or low level tragus stimulation. ${ }^{36}$ In CASA-AF, ${ }^{37,38}$ single procedure thoracoscopic surgical left atrial posterior wall isolation was not superior to extensive point-by-point posterior wall isolation plus right and left isthmus ablation and came with higher costs and less gain in QALYs. However, the surgical lesion set was quite limited and surgical learning curve effects may have affected outcome.

\section{Postoperative atrial fibrillation}

The risk of stroke and other adverse outcomes after postoperative AF (POAF) was reported from the combined datasets of the randomized POISE trials on the effects of metoprolol vs. placebo, aspirin vs. placebo, and clonidine vs. placebo. ${ }^{39}$ Patients with cardiovascular disease were undergoing non-cardiac surgery. POAF within 30 days after surgery was seen in 404 of 18117 patients and was associated with 1-year stroke incidence of $5.6 \%$ compared to $1.5 \%$ in no-POAF patients. Also, risk of death (31.3\% vs. 9.3\%) and myocardial infarction (26.2 vs. 8.2) were increased (Figure 2). Risk reduction strategies still need to be investigated. This knowledge gap was unfortunately not filled by a recent randomized trial testing the sedative dexmedetomidine against placebo to reduce new-onset POAF as well as delirium in 798 patients undergoing cardiac surgery. ${ }^{40}$ The incidence of new POAF ( $32 \%$ ) and delirium ( 15\%) did not differ between study groups.

\section{Resynchronization therapy, including His bundle, septal, and left bundle pacing}

The year 2020 saw an exponential increase in interest for His bundle (HBP) and left bundle branch area pacing (LBBAP) in cardiac resynchronization therapy (CRT). The number of implants in the USA of the most commonly used lead (Medtronic 3830), showed an increase from 2000 in 2016 to 10000 in 2018. The number of HBP related publications increased from 5 in 2014 to 75 in $2018 .^{41}$ Worldwide sales of the 3830 lead increased nine-fold between 2014 and 2018. The Twitter '\#dontdisthehis' attracted almost 1200 users within 2.5 years. ${ }^{42}$ The increased interest in HBP is likely due to the availability of better guiding catheters and the evidence that HBP is also suitable for CRT. In 2020, a few studies indicated that HBP may be equal or superior to conventional biventricular pacing (BVP) with regard to 


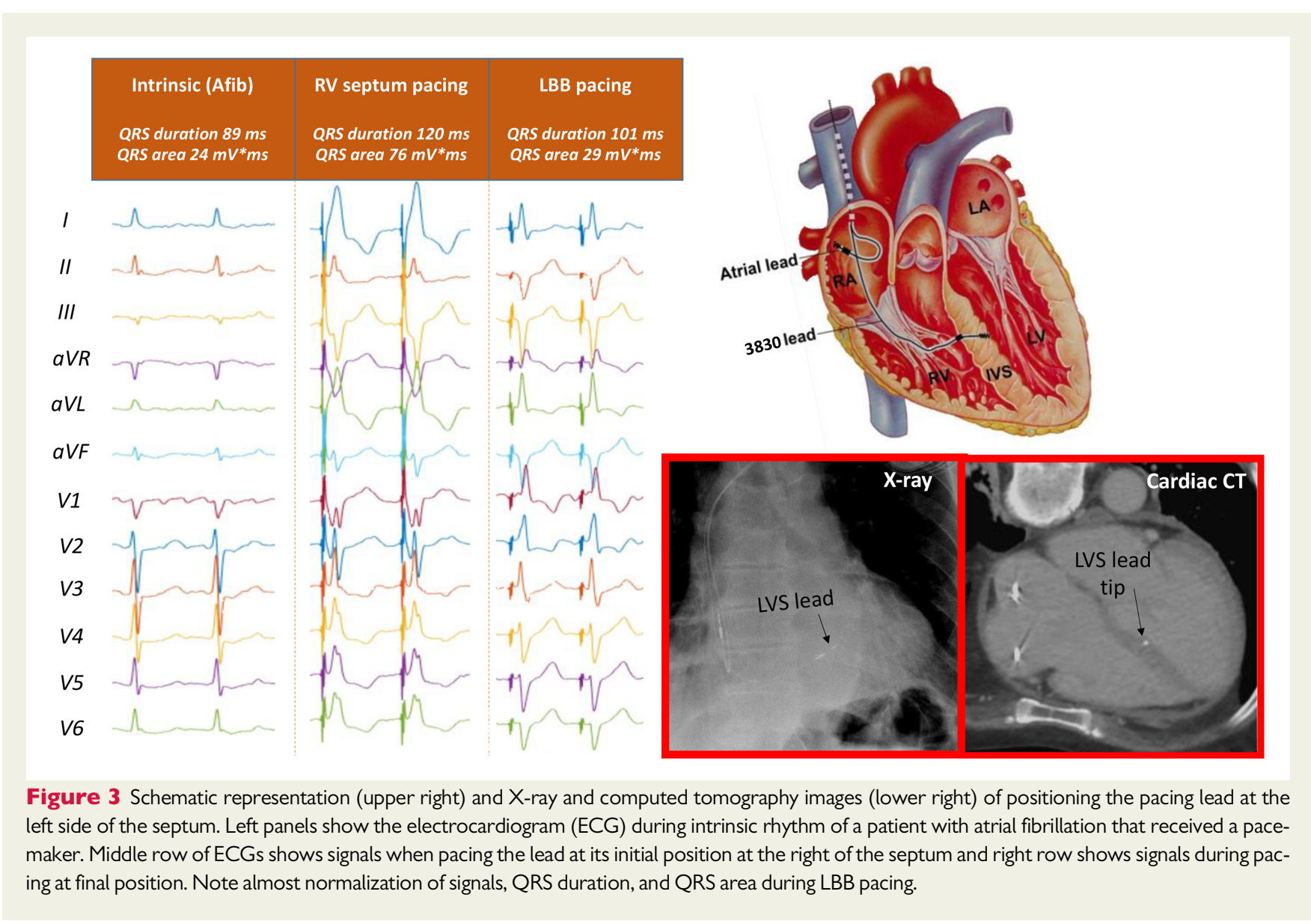

acute hemodynamic improvement, reverse remodeling and clinical outcome. ${ }^{43-45}$

In 2020, LBBAP was only 3 years old but attracted already considerable interest. For LBBAP, the 3830 lead is introduced transvenously and subsequently screwed through the interventricular septum until the tip of the lead is (almost) at the left ventricular (LV) endocardium (Figure 3). Compared to HBP, LBBAP lead implantation is easier and pacing thresholds are lower. ${ }^{46}$ Some investigators aim at capturing the left bundle branch itself, ${ }^{45}$ but others are less critical and accept any 'LV septal' lead position. ${ }^{44}$ In 2020 , a number of small single and multicenter studies appeared. Hou et al. ${ }^{46}$ performed a study in 56 patients with bradyarrhythmias and LVEF $>55 \%$. These authors found that permanent LBBAP is safe and feasible. A better maintenance of synchrony of contraction, determined using SPECT MPI phase analysis, was observed when the left bundle branch was captured. Three studies comprising a total of 116 patients with LBBAP, 49 with HBP, and 75 with BVP consistently showed a larger reduction in QRS-complex (QRS) duration in combination with a larger increase in LV ejection fraction. ${ }^{45,47,48}$

Salden et al. ${ }^{44}$ compared the acute hemodynamic and electrophysiological effects of 'LV septum pacing' with that of BVP and HBP. The three pacing modes were comparable with regards to increase in LVdP/dtmax, whilst HBP and LV septum pacing tended to provide better electrical resynchronization. An important finding was also that similar effects were observed when pacing the LV septum at the basal, equatorial and apical part of the septum. To show feasibility, safety (including lead extraction) and clinical effectiveness of these new pacing modalities, randomized studies are required comparing LBBP with HBP and BVP. A prospective randomized study is currently performed in China. ${ }^{49}$

\section{Inherited cardiac conditions, risk assessment, implantable defibrillators, and sudden death}

A novel approach to the diagnosis of Brugada syndrome $(\mathrm{BrS})$ described the utilization of autoantibody screening for $\alpha$-cardiac actin, $\alpha$-skeletal actin, keratin, and connexin-43. In total, 18/18 BrS subjects demonstrated this autoantibody profile vs. 0/8 normal controls and 0/20 cardiomyopathy cases, which included arrhythmogenic right ventricular cardiomyopathy (ARVC), hypertrophic cardiomyopathy (HCM), and dilated cardiomyopathy (DCM) patients. ${ }^{50}$ In a subgroup of $\mathrm{BrS}$ patients, each of these proteins and the sodium channel protein type 5 alpha subunit ( $\mathrm{NaV1.5}$ ) aggregated in the sarcoplasm of myocardial cells. The mechanism as to why antibodies to these proteins identified $\mathrm{BrS}$ cases is unclear but could relate to 
sarcolemmal membrane damage either due to a myocarditic process in the disease course or abnormal cell adhesion resulting in an immune response. The novelty of this study is the utilisation of a serological test to identify $\mathrm{BrS}$ subjects, which can be challenging given the transient nature of the electrocardiogram (ECG) pattern. This paper is complemented by a study investigating polygenic risk (PRS) of ECG markers to predict a positive ajmaline response. ${ }^{51}$ PRS for $\mathrm{BrS}$, baseline QRS duration, presence of Type II or III BrS ECG at baseline and family history of $\mathrm{BrS}$ were independently associated with the occurrence of a Type I BrS ECG, with good predictive accuracy (optimismcorrected C-statistic 0.74). This provides the first data to enable the combination of genetic and clinical screening to predict ajmaline responses and has implications for risk stratification.

A combined clinical and electrophysiological mapping study showed that SCN5A mutation carriers exhibit more pronounced epicardial electrical abnormalities and a more aggressive clinical presentation than non-carriers. ${ }^{52}$

Recent data support the use of drug therapy to manage patients with catecholaminergic polymorphic VT (CPVT). In a provocative paper by Van der Werf et al., ${ }^{53}$ no survival benefit from ICDs was shown in young CPVT patients surviving cardiac arrest. There are a number of caveats to this study, but the main learning point was that such patients can be treated without an ICD.

PRAETORIAN compared transvenous and subcutaneous ICDs in 849 patients $>18$ years with a class I or lia indication for ICD therapy for primary or secondary prevention, followed for 49.1 months. ${ }^{54} \mathrm{~S}$ ICD demonstrated non-inferiority of the composite primary endpoint of device-related complications and inappropriate shocks. This provides the first multicentre trial evidence that the S-ICD is as effective and safe as transvenous ICD in preventing SCD for patients not requiring brady-pacing, anti-tachycardia $V T$ pacing, or $C R T$, but challenges remain including longevity of leads and ICD, and inappropriate shocks. Concerning the latter, the UNTOUCHED study of primary prevention ICD therapy supports the PRAETORIAN data by showing an inappropriate shock-free rate of $95.9 \%$, suggesting that the new SMART PASS filter technology and appropriate high rate SICD programming may minimize inappropriate shocks in S-ICD recipients. $^{55}$

Two primary prevention ICD registries applying propensity scoring showed beneficial effects but differed concerning efficacy of ICD in women and elderly. ${ }^{56,57}$

To predict sudden arrhythmic death (SAD) in coronary artery disease, the PRE-DETERMINE investigators integrated an ECG risk score with conventional cardiovascular parameters. A high-risk ECG score incorporating contiguous Q waves, LV hypertrophy, QRS duration, and JTc prolongation was more strongly associated with SAD than non-SAD (adjusted hazard ratios 2.87 vs. 1.38 ) and the proportion of deaths due to SAD was greater in the high vs. low risk groups ( $24.9 \%$ vs. $16.5 \%) .{ }^{58}$ The addition of ECG markers to a clinical risk factor model including LVEF improved discrimination and reclassification, including correct reclassification of $28 \%$ of patients in the validation cohort. The strength of this approach is the utilization of simple bedside biomarkers to determine management, but it needs clinical validation in a randomized trial.

To conclude, The Year in Cardiovascular Medicine 2020Arrhythmias shows significant progress in the field, much of it incremental, some of it attention gathering, and some of it clearly needing further work.

\section{Conflict of interest: none declared.}

\section{References}

1. Hindricks G, Potpara T, Dagres N, Arbelo E, Bax JJ, Blomstrom-Lundqvist C, Boriani G, Castella M, Dan GA, Dilaveris PE, Fauchier L, Filippatos G, Kalman JM, La Meir M, Lane DA, Lebeau JP, Lettino M, Lip GYH, Pinto FJ, Thomas GN, Valgimigli M, Van Gelder IC, Van Putte BP, Watkins CL; Group ESCSD. 2020 ESC Guidelines for the diagnosis and management of atrial fibrillation developed in collaboration with the European Association of Cardio-Thoracic Surgery (EACTS). Eur Heart J 2021;42:373-498.

2. Brugada J, Katritsis DG, Arbelo E, Arribas F, Bax JJ, Blomström-Lundqvist C, Calkins H, Corrado D, Deftereos SG, Diller G-P, Gomez-Doblas J], Gorenek B, Grace A, Ho SY, Kaski J-C, Kuck K-H, Lambiase PD, Sacher F, Sarquella-Brugada G, Suwalski P, Zaza A, De Potter T, Sticherling C, Aboyans V, Basso C, Bocchiardo M, Budts W, Delgado V, Dobrev D, Fitzsimons D, Gevaert S, Heidbuchel H, Hindricks G, Hlivak P, Kanagaratnam P, Katus H, Kautzner J, Kriebel T, Lancellotti P, Landmesser U, Leclercq C, Lewis B, Lopatin Y, Merkely B, Paul T, Pavlović N, Petersen S, Petronio AS, Potpara T, Roffi M, Scherr D, Shlyakhto E, Simpson IA, Zeppenfeld K, Arbelo E, Arribas F, Bax JJ, BlomströmLundqvist C, Calkins H, Deftereos SG, Diller G-P, Gomez-Doblas J], Gorenek B, Grace A, Ho SY, Kaski J-C, Kuck K-H, Lambiase PD, Sacher F, Sarquella-Brugada G, Suwalski P, Zaza A, Windecker S, Aboyans V, Baigent C, Collet J-P, Dean V, Delgado V, Fitzsimons D, Gale CP, Grobbee D, Halvorsen S, Hindricks G, lung B, Jüni P, Katus HA, Landmesser U, Leclercq C, Lettino M, Lewis BS, Merkely B, Mueller C, Petersen SE, Petronio AS, Richter DJ, Roffi M, Shlyakhto E, Simpson IA, Sousa-Uva M, Touyz RM, Amara W, Grigoryan S, Podczeck-Schweighofer A, Chasnoits A, Vandekerckhove Y, Sokolovich S, Traykov V, Skoric B, Papasavvas E, Kautzner J, Riahi S, Kampus P, Parikka H, Piot O, Etsadashvili K, Stellbrink C, Manolis AS, Csanádi Z, Gudmundsson K, Erwin J, Barsheshet A, De Ponti R, Abdrakhmanov A, Jashari H, Lunegova O, Jubele K, Refaat MM, Puodziukynas A, Groben L, Grosu A, Pavlovic N, Ibtissam F, Trines SA, Poposka L, Haugaa KH, Kowalski O, Cavaco D, Dobreanu D, Mikhaylov EN, Zavatta M, Nebojša M, Hlivak P, Ferreira-Gonzalez I, Juhlin T, Reichlin T, Haouala H, Akgun T, Gupta D; ESC Scientific Document Group. 2019 ESC Guidelines for the management of patients with supraventricular tachycardia: The Task Force for the management of patients with supraventricular tachycardia of the European Society of Cardiology (ESC): Developed in collaboration with the Association for European Paediatric and Congenital Cardiology (AEPC). Eur Heart J 2020;41:655-720.

3. Van den Dries CJ, van Doorn S, Rutten FH, Oudega R, van de Leur SJCM, Elvan A, Oude Grave L, Bilo HJG, Moons KGM, Hoes AW, Geersing G-J. Integrated management of atrial fibrillation in primary care: results of the ALL-IN cluster randomized trial. Eur Heart J 2020;41:2836-2844.

4. Wijtvliet E, Tieleman RG, van Gelder IC, Pluymaekers N, Rienstra M, Folkeringa RJ, Bronzwaer P, Elvan A, Elders J, Tukkie R, Luermans J, Van Asselt A, Van Kuijk SMJ, Tijssen JG, Crijns H. Nurse-led vs. usual-care for atrial fibrillation. Eur Heart J 2020;41:634-641.

5. Pluymaekers N, Hermans ANL, van der Velden RMJ, Gawałko M, den Uijl DW, Buskes S, Vernooy K, Crijns H, Hendriks JM, Linz D. Implementation of an ondemand app-based heart rate and rhythm monitoring infrastructure for the management of atrial fibrillation through teleconsultation: TeleCheck-AF. Europace 2020; doi: 10.1093/europace/euaa201.

6. Linz D, Pluymaekers N, Hendriks JM. TeleCheck-AF for COVID-19. Eur Heart J 2020;41:1954-1955.

7. Guo $Y$, Lane DA, Wang L, Zhang H, Wang H, Zhang W, Wen J, Xing Y, Wu F, Xia Y, Liu T, Wu F, Liang Z, Liu F, Zhao Y, Li R, Li X, Zhang L, Guo J, Burnside G, Chen Y, Lip GYH, Guo Y, Lip GYH, Lane DA, Chen Y, Wang L, Eckstein J, Thomas GN, Tong L, Mei F, Xuejun L, Xiaoming L, Zhaoliang S, Xiangming S, Wei Z, Yunli X, Jing W, Fan W, Sitong Y, Xiaoqing J, Bo Y, Xiaojuan B, Yuting J, Yangxia L, Yingying S, Zhongju T, Li Y, Tianzhu L, Chunfeng N, Lili Z, Shuyan L, Zulu W, Bing X, Liming L, Yuanzhe J, Yunlong X, Xiaohong C, Fang W, Lina Z, Yihong S, Shujie J, Jing L, Nan L, Shijun L, Huixia L, Rong L, Fan L, Qingfeng G, Tianyun G, Yuan W, Xin L, Yan R, Xiaoping C, Ronghua C, Yun S, Yulan Z, Haili S, Yujie Z, Quanchun W, Weidong S, Lin W, Chan E, Guangliang S, Chen Y, Wei Z, Dandi C, Xiang H, Anding X, Xiaohan F, Ziqiang Y, Xiang G, Fulin G. Mobile health technology to improve care for patients with atrial fibrillation. J Am Coll Cardiol 2020;75:1523-1534.

8. Cox JL, Parkash R, Foster GA, Xie F, MacKillop JH, Ciaccia A, Choudhri SH, Hamilton LM, Nemis-White JM, Thabane L; Investigators I-A. Integrated Management Program Advancing Community Treatment of Atrial Fibrillation (IMPACT-AF): a cluster randomized trial of a computerized clinical decision support tool. Am Heart J 2020;224:35-46. 
9. Vinereanu D, Lopes RD, Bahit MC, Xavier D, Jiang J, Al-Khalidi HR, He W, Xian Y, Ciobanu AO, Kamath DY, Fox KA, Rao MP, Pokorney SD, Berwanger O, Tajer C, de Barros e Silva PGM, Roettig ML, Huo Y, Granger CB, Carbajales J, Gómez JNC, Principato MB, Von Wulffen MA, Acunzo JGRS, Bonato RR, Ciampi N, Marani AB, Panigadi CG, Pastura SG, Onetto LM, Moya CR, Budassi N, Valle M, Camerini D, Monjes E, Zabala F, Ricart JP, Medesani L, Campos ENO, Ferroni F, Torres MF, Fassi DO, Bosio FJD, Baztarrica GEP, Infantas TZ, Perlo D, García CF, Durán RG, Durán LG, Pettinari CA, Vico ML, Lanchiotti PV, Gómez MS, Poy CA, Grazziani FS, Laspina MJ, Poy ML, Bahit MC, Tajer C, García M, Lopes RD, de Barros e Silva PGM, Berwanger O, Egydio F, Restelli E, Kawakami A, Soares TC, Valois MV, Duarte TB, Barbosa LM, de Paola AAV, Pimenta TL, Jeronimo GDM, da Costa BSF, Coutinho EL, Guerrero AZA, Maia LN, Nakazone MA, Lemos MAT, Costa OMC, Demore AP, Brito RP, Melo CDB, Góes NC, Lorenço O, Gonçalves LOM, Nishiama K, de Lima TAM, Backes LM, de Lima Deucher KLA, Rodrigues MP, Baldissera DM, Reolão JBC, dos Santos TA, Freisleben FMB, da Silveira Kaross NL, Montovani JT, Cantarelli M, Lucion A, do Amarante L, Foscarini P, de Mello Perez C, França FR, Fialho L, Rey HCV, God EMG, Figueiredo EL, Werner GF, de Faria Garcia JC, Azevedo B, Barbosa LCV, Pardi E, Oliveira MD, Martinelli T, Cavalini RG, de Moraes MSM, Filho AML, Palmegiani E, Megid TBC, Queirantes CSP, Cruz TSA, He P, Zhou X, Zhou N, Zhao M, Yu J, Cheng Y, Wang L, Liu L, Liu S, Li L, Li A, Yuan X, Xia G, Wang Z, Li C, Chen W, Tang Q, Tang Q, Xu W, Zhu X, Hou B, Ma W, Wang C, Jin Q, Wang J, Xie X, Joseph J, Davidson D, Thomas JK, Kunjumon TV, Stephen T, Fatania K, Rathi G, Garala K, Doshi D, Varghese K, Ma S, Sheeba L, Kumar S, Rao MB, Rao KD, Vuriya AK, Kumari MP, Khandelwal B, Dhakal M, Srivastava N, Khatri D, Moktan S, Gupta R, Roy S, Kumawat K, Sharma M, Sharma KK, Jathappa N, Lokesh BH, Kariyappa S, Leela AC, Someshwara KC, Desai S, Desai D, Patel K, Patel S, Bhartiya M, Mahanta BN, Dutta DJ, Rajkonwer G, Gupta SK, Mishra AK, Singh A, Kesarwani N, Kumar S, Chioncel O, Balan A, Carstea N, Chitoiu GT, Cornaciu S, Cinteza M, Rimbas RC, Dimulescu D, lonescu L, Fruntelata A, Dumitru N, Gaita D, Pleava R, Iliesiu A, Uscoiu G, Lighezan D, Buzas R, Sinescu CJ, Avram A-M, Baldea S, Galrinho RD, Magda SL, Matei L; Investigators I-A. A multifaceted intervention to improve treatment with oral anticoagulants in atrial fibrillation (IMPACT-AF): an international, clusterrandomised trial. Lancet 2017;390:1737-1746.

10. Tzikas A, Samaras A, Kartas A, Vasdeki D, Fotos G, Dividis G, Paschou E, Forozidou E, Tsoukra P, Kotsi E, Goulas I, Karvounis H, Giannakoulas G. Motivational Interviewing to Support Oral AntiCoagulation adherence in patients with non-valvular Atrial Fibrillation (MISOAC-AF): a randomised clinical trial. Eur Heart J Cardiovasc Pharmacother 2020;doi: 10.1093/ehjcvp/pvaa039.

11. Kunneman M, Branda ME, Hargraves IG, Sivly AL, Lee AT, Gorr H, Burnett B, Suzuki T, Jackson EA, Hess E, Linzer M, Brand-McCarthy SR, Brito JP, Noseworthy PA, Montori VM; for the Shared Decision Making for Atrial Fibrillation (SDM4Afib) Trial Investigators. Assessment of shared decision-making for stroke prevention in patients with atrial fibrillation: a randomized clinical trial. JAMA Intern Med 2020;180:1215.

12. Elliott AD, Linz D, Mishima R, Kadhim K, Gallagher C, Middeldorp ME, Verdicchio CV, Hendriks JML, Lau DH, La Gerche A, Sanders P. Association between physical activity and risk of incident arrhythmias in 402406 individuals: evidence from the UK Biobank cohort. Eur Heart J 2020;41:1479-1486.

13. Voskoboinik A, Kalman JM, De Silva A, Nicholls T, Costello B, Nanayakkara S, Prabhu S, Stub D, Azzopardi S, Vizi D, Wong G, Nalliah C, Sugumar H, Wong M, Kotschet E, Kaye D, Taylor AJ, Kistler PM. Alcohol abstinence in drinkers with atrial fibrillation. N Engl J Med 2020;382:20-28.

14. Linz D, Crijns $\mathrm{H}$. Alcohol abstinence in drinkers with atrial fibrillation. $N$ Engl J Med 2020;382:1768.

15. Kirchhof P, Camm AJ, Goette A, Brandes A, Eckardt L, Elvan A, Fetsch T, van Gelder IC, Haase D, Haegeli LM, Hamann F, Heidbüchel H, Hindricks G, Kautzner J, Kuck KH, Mont L, Ng GA, Rekosz J, Schoen N, Schotten U, Suling A, Taggeselle J, Themistoclakis S, Vettorazzi E, Vardas P, Wegscheider K, Willems S, Crijns $\mathrm{H}$, Breithardt $\mathrm{G}$. Early rhythm-control therapy in patients with atrial fibrillation. N Engl J Med 2020;383:1305-1316.

16. Camm AJ, Kirchhof P, Lip GYH, Schotten U, Savelieva I, Ernst S, Van Gelder IC, Al-Attar N, Hindricks G, Prendergast B, Heidbuchel H, Alfieri O, Angelini A, Atar D, Colonna P, De Caterina R, De Sutter J, Goette A, Gorenek B, Heldal M, Hohloser SH, Kolh P, Le Heuzey J-Y, Ponikowski P, Rutten FH, Vahanian A, Auricchio A, Bax J, Ceconi C, Dean V, Filippatos G, Funck-Brentano C, Hobbs R, Kearney P, McDonagh T, Popescu BA, Reiner Z, Sechtem U, Sirnes PA, Tendera M, Vardas PE, Widimsky P, Vardas PE, Agladze V, Aliot E, Balabanski T, Blomstrom-Lundqvist C, Capucci A, Crijns H, Dahlof B, Folliguet T, Glikson M, Goethals M, Gulba DC, Ho SY, Klautz RJM, Kose S, McMurray J, Perrone Filardi P, Raatikainen P, Salvador MJ, Schalij MJ, Shpektor A, Sousa J, Stepinska J, Uuetoa $\mathrm{H}$, Zamorano JL, Zupan I; Developed with the special contribution of the European Heart Rhythm Association (EHRA). Guidelines for the management of atrial fibrillation: the Task Force for the Management of Atrial Fibrillation of the European Society of Cardiology (ESC). Eur Heart J 2010;31:2369-2429.
17. Camm AJ, Lip GYH, De Caterina R, Savelieva I, Atar D, Hohnloser SH, Hindricks G, Kirchhof P, Bax JJ, Baumgartner H, Ceconi C, Dean V, Deaton C, Fagard R, Funck-Brentano C, Hasdai D, Hoes A, Kirchhof P, Knuuti J, Kolh P, McDonagh T, Moulin C, Popescu BA, Reiner Ž, Sechtem U, Sirnes PA, Tendera M, Torbicki A, Vahanian A, Windecker S, Vardas P, Al-Attar N, Alfieri O, Angelini A, Blömstrom-Lundqvist C, Colonna P, De Sutter J, Ernst S, Goette A, Gorenek B, Hatala R, Heidbüchel $H$, Heldal M, Kristensen SD, Kolh P, Le Heuzey J-Y, Mavrakis H, Mont L, Filardi PP, Ponikowski P, Prendergast B, Rutten FH, Schotten U, Van Gelder IC, Verheugt FWA; Authors/Task Force Members. 2012 focused update of the ESC Guidelines for the management of atrial fibrillation: an update of the 2010 ESC Guidelines for the management of atrial fibrillation, developed with the special contribution of the European Heart Rhythm Association. Europace 2012;14:1385-1413.

18. Kirchhof P, Benussi S, Kotecha D, Ahlsson A, Atar D, Casadei B, Castella M, Diener $\mathrm{H}-\mathrm{C}$, Heidbuchel $\mathrm{H}$, Hendriks J, Hindricks G, Manolis AS, Oldgren J, Popescu BA, Schotten U, Van Putte B, Vardas P, Agewall S, Camm J, Baron Esquivias G, Budts W, Carerj S, Casselman F, Coca A, De Caterina R, Deftereos S, Dobrev D, Ferro JM, Filippatos G, Fitzsimons D, Gorenek B, Guenoun M, Hohnloser SH, Kolh P, Lip GYH, Manolis A, McMurray J, Ponikowski P, Rosenhek R, Ruschitzka F, Savelieva I, Sharma S, Suwalski P, Tamargo JL, Taylor C), Van Gelder IC, Voors AA, Windecker S, Zamorano JL, Zeppenfeld K. 2016 ESC Guidelines for the management of atrial fibrillation developed in collaboration with EACTS. Eur Heart J 2016;37:2893-2962.

19. Wyse DG, Waldo AL, DiMarco JP, Domanski MJ, Rosenberg Y, Schron EB, Kellen JC, Greene HL, Mickel MC, Dalquist JE, Corley SD; Atrial Fibrillation Follow-up Investigation of Rhythm Management (AFFIRM) Investigators. A comparison of rate control and rhythm control in patients with atrial fibrillation. $N$ Engl J Med 2002;347:1825-1833.

20. Van Gelder IC, Hagens VE, Bosker HA, Kingma JH, Kamp O, Kingma T, Said SA, Darmanata JI, Timmermans AJ, Tijssen JG, Crijns HJ. A comparison of rate control and rhythm control in patients with recurrent persistent atrial fibrillation. $N$ Engl J Med 2002;347:1834-1840.

21. Marrouche NF, Brachmann J, Andresen D, Siebels J, Boersma L, Jordaens L, Merkely B, Pokushalov E, Sanders P, Proff J, Schunkert H, Christ H, Vogt J, Bänsch D. Catheter ablation for atrial fibrillation with heart failure. N Engl J Med 2018;378:417-427.

22. Packer DL, Mark DB, Robb RA, Monahan KH, Bahnson TD, Poole JE, Noseworthy PA, Rosenberg YD, Jeffries N, Mitchell LB, Flaker GC, Pokushalov E, Romanov A, Bunch TJ, Noelker G, Ardashev A, Revishvili A, Wilber DJ, Cappato R, Kuck KH, Hindricks G, Davies DW, Kowey PR, Naccarelli GV, Reiffel JA, Piccini JP, Silverstein AP, Al-Khalidi HR, Lee KL, Investigators C; for the CABANA Investigators. Effect of catheter ablation vs antiarrhythmic drug therapy on mortality, stroke, bleeding, and cardiac arrest among patients with atrial fibrillation: the CABANA randomized clinical trial. JAMA 2019;321:1261-1274.

23. Nieuwlaat R, Prins MH, Le Heuzey JY, Vardas PE, Aliot E, Santini M, Cobbe SM, Widdershoven JW, Baur LH, Levy S, Crijns HJ. Prognosis, disease progression, and treatment of atrial fibrillation patients during 1 year: follow-up of the Euro Heart Survey on atrial fibrillation. Eur Heart J 2008;29:1181-1189.

24. Healey JS, Oldgren J, Ezekowitz M, Zhu J, Pais P, Wang J, Commerford P, Jansky P, Avezum A, Sigamani A, Damasceno A, Reilly P, Grinvalds A, Nakamya J, Aje A, Almahmeed W, Moriarty A, Wallentin L, Yusuf S, Connolly SJ, Registry R-L; Cohort Study I. Occurrence of death and stroke in patients in 47 countries 1 year after presenting with atrial fibrillation: a cohort study. Lancet 2016;388: 1161-1169.

25. Wazni OM, Dandamudi G, Sood N, Hoyt R, Tyler J, Durrani S, Niebauer M, Makati K, Halperin B, Gauri A, Morales G, Shao M, Cerkvenik J, Kaplon RE, Nissen SE; Investigators SAFT. Cryoballoon ablation as initial therapy for atrial fibrillation. N Engl J Med 2020;doi: 10.1056/NEJMoa2029554.

26. Andrade JG, Wells GA, Deyell MW, Bennett M, Essebag V, Champagne J, Roux JF, Yung D, Skanes A, Khaykin Y, Morillo C, Jolly U, Novak P, Lockwood E, Amit G, Angaran P, Sapp J, Wardell S, Lauck S, Macle L, Verma A; Investigators E-A. Cryoablation or drug therapy for initial treatment of atrial fibrillation. $N$ Engl J Med 2020.

27. Hawkins NM, Scheuermeyer FX, Youngson E, Sandhu RK, Ezekowitz JA, Kaul P, McAlister FA. Impact of cardiology follow-up care on treatment and outcomes of patients with new atrial fibrillation discharged from the emergency department. Europace 2020;22:695-703.

28. Crijns H, Wijtvliet EPJ, Pluymaekers N, Van Gelder IC. Newly discovered atrial fibrillation: who(se) care(s)?. Europace 2020;22:677-678.

29. Stiell IG, Sivilotti MLA, Taljaard M, Birnie D, Vadeboncoeur A, Hohl CM, McRae $A D$, Rowe $B H$, Brison RJ, Thiruganasambandamoorthy $V$, Macle L, Borgundvaag B, Morris J, Mercier E, Clement CM, Brinkhurst J, Sheehan C, Brown E, Nemnom M-J, Wells GA, Perry JJ. Electrical versus pharmacological cardioversion for emergency department patients with acute atrial fibrillation (RAFF2): a partial factorial randomised trial. Lancet 2020;395:339-349. 
30. Chen S, Purerfellner H, Meyer C, Acou WJ, Schratter A, Ling Z, Liu S, Yin Y, Martinek M, Kiuchi MG, Schmidt B, Chun KRJ. Rhythm control for patients with atrial fibrillation complicated with heart failure in the contemporary era of catheter ablation: a stratified pooled analysis of randomized data. Eur Heart J 2020; 41:2863-2873.

31. Blomström-Lundqvist C, Gizurarson S, Schwieler J, Jensen SM, Bergfeldt L, Kennebäck G, Rubulis A, Malmborg H, Raatikainen P, Lönnerholm S, Höglund N, Mörtsell D. Effect of catheter ablation vs antiarrhythmic medication on quality of life in patients with atrial fibrillation: the CAPTAF randomized clinical trial. JAMA 2019;321:1059-1068.

32. Mark DB, Anstrom KJ, Sheng S, Piccini JP, Baloch KN, Monahan KH, Daniels MR, Bahnson TD, Poole JE, Rosenberg Y, Lee KL, Packer DL; for the CABANA Investigators. Effect of catheter ablation vs medical therapy on quality of life among patients with atrial fibrillation: the CABANA randomized clinical trial. JAMA 2019;321:1275-1285.

33. Martinek M, Purerfellner $H$, Blessberger $H$, Pruckner $G$. Impact of catheter ablation therapy for atrial fibrillation on healthcare expenditures in a middle European cohort. Europace 2020;22:576-583.

34. Kim D, Yang PS, Sung JH, Jang E, Yu HT, Kim TH, Uhm JS, Kim JY, Pak HN, Lee MH, Lip GYH, Joung B. Less dementia after catheter ablation for atrial fibrillation: a nationwide cohort study. Eur Heart J 2020;doi:10.1093/eurheartj/ehaa726.

35. Steinberg JS, Shabanov V, Ponomarev D, Losik D, Ivanickiy E, Kropotkin E, Polyakov K, Ptaszynski P, Keweloh B, Yao C), Pokushalov EA, Romanov AB. Effect of renal denervation and catheter ablation vs catheter ablation alone on atrial fibrillation recurrence among patients with paroxysmal atrial fibrillation and hypertension: the ERADICATE-AF randomized clinical trial. JAMA 2020;323: 248-255.

36. Stavrakis S, Stoner JA, Humphrey MB, Morris L, Filiberti A, Reynolds JC, Elkholey K, Javed I, Twidale N, Riha P, Varahan S, Scherlag BJ, Jackman WM, Dasari TW, Po SS. TREAT AF (Transcutaneous Electrical Vagus Nerve Stimulation to Suppress Atrial Fibrillation): a randomized clinical trial. JACC Clin Electrophysiol 2020;6:282-291.

37. Haldar SK, Jones DG, Bahrami T, De Souza A, Panikker S, Butcher C, Khan H, Yahdav R, Jarman J, Mantziari L, Nyktari E, Mohiaddin R, Hussain W, Markides V, Wong $T$. Catheter ablation vs electrophysiologically guided thoracoscopic surgical ablation in long-standing persistent atrial fibrillation: the CASA-AF Study. Heart Rhythm 2017;14:1596-1603.

38. Haldar S, Khan HR, Boyalla V, Kralj-Hans I, Jones S, Lord J, Onyimadu O, Satishkumar A, Bahrami T, De Souza A, Clague JR, Francis DP, Hussain W, Jarman JW, Jones DG, Chen Z, Mediratta N, Hyde J, Lewis M, Mohiaddin R, Salukhe TV, Murphy C, Kelly J, Khattar RS, Toff WD, Markides V, McCready J, Gupta D, Wong T; Investigators C-A. Catheter ablation vs. thoracoscopic surgical ablation in long-standing persistent atrial fibrillation: CASA-AF randomized controlled trial. Eur Heart / 2020;doi:10.1093/eurheartj/ehaa658.

39. Conen D, Alonso-Coello P, Douketis J, Chan MTV, Kurz A, Sigamani A, Parlow JL, Wang CY, Villar JC, Srinathan SK, Tiboni M, Malaga G, Guyatt G, Sivakumaran S, Rodriguez Funes MV, Cruz P, Yang H, Dresser GK, Alvarez-Garcia J, Schricker T, Jones PM, Drummond LW, Balasubramanian K, Yusuf S, Devereaux PJ. Risk of stroke and other adverse outcomes in patients with perioperative atrial fibrillation 1 year after non-cardiac surgery. Eur Heart J 2020;41:645-651.

40. Turan A, Duncan A, Leung S, Karimi N, Fang J, Mao G, Hargrave J, Gillinov M, Trombetta C, Ayad S, Hassan M, Feider A, Howard-Quijano K, Ruetzler K, Sessler DI, Bergese S, De Oliveira G, Honar H, Niazi A, Elliott K, Hamadnalla H, Chodavarapu P, Bajracharya G, Fitzgerald P, Cuko E, Akhtar Z, Lokhande C, Khan MZ, Khoshknabi D, Riter Q, Hutcherson M, Yagar S, Glosse L, Saha P, Raza $S$. Dexmedetomidine for reduction of atrial fibrillation and delirium after cardiac surgery (DECADE): a randomised placebo-controlled trial. Lancet 2020;396: 177-185.

41. Barakat AF, Inashvili A, Alkukhun L, Shalaby AA, Wang NC, Bhonsale A, Wann D, Gardner M, Khan M, Bidani S, Skowronski J, Jain S, Voigt A, Bazaz R, Estes NAM, 3rd, Saba S, Kancharla K. Use trends and adverse reports of SelectSecure 3830 lead implantations in the United States: implications for His Bundle Pacing. Circ Arrhythm Electrophysiol 2020;13:e008577.

42. Beer D, Dandamudi G, Mandrola JM, Friedman PA, Vijayaraman P. His-bundle pacing: impact of social media. Europace 2019;21:1445-1450.

43. Moriña-Vázquez $P$, Moraleda-Salas MT, Manovel-Sánchez AJ, Fernández-Gómez JM, Arce-Léon Á, Venegas-Gamero J, Barba-Pichardo R. Early improvement of left ventricular ejection fraction by cardiac resynchronization through $\mathrm{His}$ bundle pacing in patients with heart failure. Europace 2020;22:125-132.

44. Salden F, Luermans J, Westra SW, Weijs B, Engels EB, Heckman LIB, Lamerichs LJM, Janssen MHG, Clerx KJH, Cornelussen R, Ghosh S, Prinzen FW, Vernooy K. Short-term hemodynamic and electrophysiological effects of cardiac resynchronization by left ventricular septal pacing. J Am Coll Cardiol 2020;75:347-359.

45. Wu S, Su L, Vijayaraman P, Zheng R, Cai M, Xu L, Shi R, Huang Z, Whinnett ZI, Huang $W$. Left bundle branch pacing for cardiac resynchronization therapy: nonrandomized on-treatment comparison with His bundle pacing and biventricular pacing. Can J Cardiol 2020;doi: 10.1016/j.cjca.2020.04.037.

46. Hou X, Qian Z, Wang Y, Qiu Y, Chen X, Jiang H, jiang Z, Wu H, Zhao Z, Zhou $W$, Zou J. Feasibility and cardiac synchrony of permanent left bundle branch pacing through the interventricular septum. Europace 2019;21:1694-1702.

47. Huang W, Wu S, Vijayaraman P, Su L, Chen X, Cai B, Zou J, Lan R, Fu G, Mao G, Ellenbogen KA, Whinnett ZI, Tung R. Cardiac resynchronization therapy in patients with nonischemic cardiomyopathy using left bundle branch pacing. JACC Clin Electrophysiol 2020;6:849-858.

48. Guo J, Li L, Xiao G, Ye T, Huang X, Meng F, Li Q, Chen S, Cai B. Remarkable response to cardiac resynchronization therapy via left bundle branch pacing in patients with true left bundle branch block. Clin Cardiol 2020;43:1460-1468.

49. Cheng L, Zhang J, Wang Z, Zhou M, Liang Z, Zhao L, Chen J, Wu Y. Efficacy and safety of left bundle branch area pacing versus biventricular pacing in heart failure patients with left bundle branch block: study protocol for a randomised controlled trial. BMJ Open 2020;10:e036972.

50. Chatterjee D, Pieroni M, Fatah M, Charpentier F, Cunningham KS, Spears DA Chatterjee D, Suna G, Bos JM, Ackerman MJ, Schulze-Bahr E, Dittmann S, Notarstefano PG, Bolognese L, Duru F, Saguner AM, Hamilton RM. An autoantibody profile detects Brugada syndrome and identifies abnormally expressed myocardial proteins. Eur Heart J 2020;41:2878-2890.

51. Tadros R, Tan HL, El Mathari S, Kors JA, Postema PG, Lahrouchi N, Beekman L, Radivojkov-Blagojevic M, Amin AS, Meitinger T, Tanck MW, Wilde AA, Bezzina CR; ESCAPE-NET Investigators. Predicting cardiac electrical response to sodium-channel blockade and Brugada syndrome using polygenic risk scores. Eur Heart J 2019;40:3097-3107.

52. Ciconte G, Monasky MM, Santinelli V, Micaglio E, Vicedomini G, Anastasia L, Negro G, Borrelli V, Giannelli L, Santini F, de Innocentiis C, Rondine R, Locat ET, Bernardini A, Mazza Bc Mecarocci V, Calovic Z, Ghiroldi A, D'Imperio S, Benedetti S, Di Resta C, Rivolta I, Casari G, Petretto E, Pappone C. Brugada syndrome genetics is associated with phenotype severity. Eur Heart J 2020;doi: 10.1093/eurheartj/ehaa942.

53. Van der Werf C, Lieve KV, Bos JM, Lane CM, Denjoy I, Roses-Noguer F, Aiba T, Wada Y, Ingles J, Leren IS, Rudic B, Schwartz PJ, Maltret A, Sacher F, Skinner JR, Krahn AD, Roston TM, Tfelt-Hansen J, Swan H, Robyns T, Ohno S, Roberts JD, van den Berg MP, Kammeraad JA, Probst V, Kannankeril PJ, Blom NA, Behr ER, Borggrefe M, Haugaa KH, Semsarian C, Horie M, Shimizu W, Till JA, Leenhardt A, Ackerman MJ, Wilde AA. Implantable cardioverter-defibrillators in previously undiagnosed patients with catecholaminergic polymorphic ventricular tachycardia resuscitated from sudden cardiac arrest. Eur Heart J 2019;40:2953-2961.

54. Knops RE, Olde Nordkamp LRA, Delnoy PHM, Boersma LVA, Kuschyk J, ElChami MF, Bonnemeier H, Behr ER, Brouwer TF, Kääb S, Mittal S, Quast ABE, Smeding L, van der Stuijt W, de Weger A, de Wilde KC, Bijsterveld NR, Richter S, Brouwer MA, de Groot JR, Kooiman KM, Lambiase PD, Neuzil P, Vernooy K, Alings M, Betts TR, Bracke F, Burke MC, de Jong J, Wright DJ, Tijssen JGP, Wilde AAM. Subcutaneous or transvenous defibrillator therapy. N Engl J Med 2020;383 526-536.

55. Gold MR, Lambiase PD, El-Chami MF, Knops RE, Aasbo JD, Bongiorni MG, Russo AM, Deharo JC, Burke MC, Dinerman J, Barr CS, Shaik N, Carter N, Stoltz T, Stein KM, Brisben AJ, Boersma LV; Investigators U. Primary results from the Understanding Outcomes with the S-ICD in Primary Prevention Patients with Low Ejection Fraction (UNTOUCHED) trial. Circulation 2020;143:7-17.

56. Schrage B, Uijl A, Benson L, Westermann D, Stahlberg M, Stolfo D, Dahlstrom $U$, Linde $C$, Braunschweig F, Savarese G. Association between use of primaryprevention implantable cardioverter-defibrillators and mortality in patients with heart failure: a prospective propensity score-matched analysis from the Swedish Heart Failure Registry. Circulation 2019;140:1530-1539.

57. Zabel M, Willems R, Lubinski A, Bauer A, Brugada J, Conen D, Flevari P, Hasenfuß G, Svetlosak M, Huikuri HV, Malik M, Pavlović N, Schmidt G, Sritharan R, Schlögl S, Szavits-Nossan J, Traykov V, Tuinenburg AE, Willich SN, Harden M, Friede T, Svendsen JH, Sticherling C, Merkely B, Merkely B, Perge P, Sallo Z, Szeplaki G, Szegedi N, Nagy KV, Zabel M, Lüthje L, Schlögl S, Sritharan R, Haarmann H, Bergau L, Seegers J, Hasenfuß G, Munoz-Exposito P, Tichelbäcker T, Kirova A, Hasenfuß G, Friede T, Zabel M, Schlögl S, Friede T, Harden M, Malik M, Hnatkova K, Vos MA, Willich SN, Reinhold T, Willems R, Vandenberk B, Klinika M, Szavits-Nossan J, Rotkvić L, Flevari P, Katsimardos A, Katsaras D, Hatala R, Svetlosak M, Lubinski A, Kuczejko T, Hansen J, Sticherling C, Conen D, Pavlović N, Manola Š, Vinter O, Benko I, Tuinenburg A, Sprenkeler D, Smoczynska A, Vos MA, Bauer A, Meyer-Zürn C, Eick C, Svendsen JH, Brugada J, Arbelo E, Kaliska G, Martinek J, Schmidt G, Dommasch M, Steger A, Kääb S, Bauer A, Sinner MF, Rizas KD, Hamm W, Traykov V, Cygankiewicz I, Ptaszyński P, Kaczmarek K, Poddebska I, lovev S, Novotný T, Kozak M, Huikuri H, Kenttä T, Pelli A, Kasprzak JD, Qavoq D, Brusich S, Avdovic E, Klasan M, Galuszka J, Taborsky M, Velchev V, Dissmann R, Shalganov T, Guzik P, Krauze T, Bimmel D, Lieberz C, Ludwigsburg K, Stefanow S, Rüb N, Wolpert C, Seegers J, Meier LS, Behrens S, Jurisic Z, Braunschweig F, Blaschke F, Pieske B, Bakotic Z, Anic A 
Weiden K, Schwinger RHG, Platonov P, Grönefeld G, Klingenheben T, Merkely B, Perge P, Sallo Z, Szeplaki G, Szegedi N, Nagy KV, Zabel M, Lüthje L, Schlögl S, Sritharan R, Haarmann H, Bergau L, Seegers J, Hasenfuß G, Munoz-Exposito P, Tichelbäcker T, Kirova A, Hasenfuß G, Friede T, Zabel M, Schlögl S, Friede T, Harden M, Malik M, Hnatkova K, Vos MA, Willich SN, Reinhold T, Willems R, Vandenberk B, Klinika M, Szavits-Nossan J, Rotkvić L, Flevari P, Katsimardos A, Katsaras D, Hatala R, Svetlosak M, Lubinski A, Kuczejko T, Hansen J, Sticherling C, Conen D, Pavlović N, Manola Š, Vinter O, Benko I, Tuinenburg A, Sprenkeler D, Smoczynska A, Vos MA, Bauer A, Meyer-Zürn C, Eick C, Svendsen JH, Brugada J, Arbelo E, Kaliska G, Martinek J, Schmidt G, Dommasch M, Steger A, Kääb S, Bauer A, Sinner MF, Rizas KD, Hamm W, Traykov V, Cygankiewicz I, Ptaszyński P, Kaczmarek K, Poddebska I, lovev S, Novotný T, Kozak M, Huikuri H, Kenttä T, Pelli A, Kasprzak JD, Qavoq D, Brusich S, Avdovic E, Klasan M,
Galuszka J, Taborsky M, Velchev V, Dissmann R, Shalganov T, Guzik P, Krauze T, Bimmel D, Lieberz C, Ludwigsburg K, Stefanow S, Rüb N, Wolpert C, Seegers J, Meier LS, Behrens S, Jurisic Z, Braunschweig F, Blaschke F, Pieske B, Bakotic Z, Anic A, Weiden K, Schwinger RHG, Platonov P, Grönefeld G, Klingenheben T; EU-CERT-ICD Study Investigator. Clinical effectiveness of primary prevention implantable cardioverter-defibrillators: results of the EU-CERT-ICD controlled multicentre cohort study. Eur Heart J 2020;41:3437-3447.

58. Chatterjee NA, Tikkanen JT, Panicker GK, Narula D, Lee DC, Kentta T, Junttila JM, Cook NR, Kadish A, Goldberger J], Huikuri HV, Albert CM; for the PREDETERMINE Investigators. Simple electrocardiographic measures improve sudden arrhythmic death prediction in coronary disease. Eur Heart J 2020;41: 1988-1999.

\section{Corrigendum}

doi:10.1093/eurheartj/ehaa798

Online publish-ahead-of-print 8 October 2020

Corrigendum to: 2020 ESC Guidelines for the diagnosis and management of atrial fibrillation developed in collaboration with the European Association of Cardio-Thoracic Surgery (EACTS) [Eur HeartJ (2020); doi:10.1093/eurheartj/ehaa612].

In the originally published version of this manuscript, several errors were noted and listed in this corrigendum.

Upon original publication, Table 11, indicated that the reduction of Edoxaban doses was "30 mg o.d./15 mg o.d." and the following drugs under concomitant use involved this reduction: "verapamil, quinidine or dronedarone". The reduction of Edoxaban doses should have read: "30 mg o.d.". The following drugs under concomitant use involving this reduction should have read: "dronedarone, ciclosporine, erythromycin, or ketoconazole".

Upon the original publication, Figure 2, omitted the following: “Di Carlo, et al. Europace, 2019; 21:1468-1475. PMID: 31131389”. This has been added to the figure legend.

Upon the original publication, Figure 3, included "(non-Caucasian)" Summary of risk factors for incident AF. This has now been deleted.

Upon the original publication, there were inaccuracies within the text in the following areas: in footnote c to Figure 17; in the title and; in the "Authors/Task Force Members" footnote.

These errors have now been corrected online. 